\title{
ДЕЛО ПАВЛА ФЛОРЕНСКОГ „МИСАО И ЈЕЗИК” У СВЕТЛУ САВРЕМЕНИХ ПРОУЧАВАЬА ЈЕЗИКА И МИШЉЕЬА
}

\begin{abstract}
У овом раду представљају се, анализирају и коментаришу идеје руског филозофа Павла Флоренског о језику и мишљењу. Посебно су значајна његова запажања и открића о природи речи, као основних елемената језика, и концепата као нуклеуса мишљења. Иако Флоренски реч сматра примарном језичком јединицом, он се у својој књизи „Мисао и језик" такође бави и синтаксом, па чак и прагматиком.

Кључне речи: Павле Флоренски, језик, мишљење, реч, семантика, синтакса, прагматика.
\end{abstract}

\section{1. Увод}

Мисаона оригиналност и дубока филозофска запитаност која дотиче већину суштинских општелингвистичких питања надахнули су нас да напишемо овај скромни рад о идејама руског теолога Павла Флоренског. Рад је првенствено посвећен његовим промишљањима о природи концепата, речи и реченица.

Он није био пророк већ аутентични научник, изумитељ и филозоф. Спојио је физичку и небеску механику са квантним енергијама атома, али и језика и мишљења. Другим речима, спојио је Максвела, Аристотела и Хум-

*tijana.asic@gmail.com

** Овај рад је урађен у оквиру пројекта Министарства просвете, науке и технолошког развоја Динамика структура савременог српског језика, бр. 178014. 
болта и, попут астрофизичара Карла Ровелија ${ }^{1}$, показао да ни квантна механика, а како ћемо у наставку показати, ни генеративна граматика, коју је овај геније наслутио, не могу објаснити суштину ствари у универзуму постојања, мисли и језика. Напоменимо да се целокупно стваралаштво Флоренског заснива на принципу чуђења и запитаности над свим тајнама овог истовремено и сложеног и једноставног света, из чега проистиче и његово дубоко и далекосежно занимање за језички феномен.

„Можемо, ипак, довољно приметити и ону закониту основу чуђења пред сврховитошћу коју добијамо у суштини ствари (уколико се њихови појмови могу конструисати). Јединство различитих правила (јединство из истог принципа) изазива чуђење, но сва су та правила синтетичка; она не следе из појма о објекту, на пример, о кругу: то име је потребно да би тај објекат био дат у сазревању. Тада то јединство почиње да изгледа тако као да емпиријски има спољашњу, од наше моћи замишљања независну основу правила, и да је, дакле, подударање објеката са захтевима уму својствених правила само по себи случајно, а то значи да је могуће једино посредством сврхе, директно усмерене на њега" (Флоренски 2018: 44). ${ }^{2}$

\section{2. Кратка биографија Павла Флоренског}

Познати свештеник и теолог Павел Александрович Флоренски рођен је 1882. године у Јевлаку. На Московском универзитету завршио је физику и математику. Након дипломирања, Павел Флоренски је ушао у Московску теолошку академију. Године 1911. постао је свештеник и наредних десет година провео у Сергијевом Посаду, где је служио у цркви Уточишта сестара милосрдница Црвеног крста. Почетак Револуције религиозни мислилац сматра знаком апокалипсе. Ипак, није био изненађен догађајима из 1917. године, јер је током младости говорио о духовној кризи Русије и њеном блиском колапсу због губитка националних и духовних темеља. Када је совјетска власт ${ }^{3}$ почела да им одузима имовину, Флоренски је почео да говори у одбрану кључних православних цркава. Године 1920. добио је прве осуде Чека, у којима је филозоф оптужен за стварање забрањеног монархистичког круга.

Упркос тешким временима револуције и грађанског рата, Павле Флоренски је наставио да пише нове теоријске радове. Овај „руски Леонардо да Винчи” предавао је о разним темама из природних, техничких и друштвених наука. Веровао је да теологија и филозофија имају заједничке корене. Међутим, његово слободоумље и његова религиозност стали су на пут младој совјетској држави. Године 1937, на врхунцу Великог терора, специјална јединица НКВД осудила га је на смрт. Смртна казна извршена је 25. новем-

\footnotetext{
${ }^{1}$ Астрофизичар Карло Ровели (2018: 122-123) каже: „Ми свет, дакле, описујемо онаквим какав се догађа, а не онаквим какав је. Њутнова механика, Максвелове једначине, квантна механика итд. нам само казују како се одвијају догађаји, али не какве су и ствари.”

${ }^{2}$ У генеративном механизму коерције (в. Пустејовски 1995) речи бивају у синтаскичко-семантичком смислу уздигнуте на ниво реченице. На пример, у исказу Отишли су пре десерта, синтагма пре десерта заправо означава зависну временску реченицу Пре него што је послужен decepm.

${ }^{3}<$ https://sr.puntomarinero.com/soviet-power-definition-history-and/>, 20.10.2020.
} 
бра, недалеко од Лењинграда, на месту које је сада познато као Левашовска пустара.

\section{3. Појам речи код Флоренског}

У својој књизи Мисао и језик (в. издање из 2018) Флоренски исправно запажа да се описивање, као говор, састоји од речи. Али, он истиче да су речи пре свега конкретне представе, уметничка дела, макар и малог формата. Потом, на истом месту, вели да „свакој речи, а подједнако и њиховим склоповима, одговара нека очигледност, и та се очигледност у суштини ни по чему не разликује од сликовитости физичких модела или математичких симбола" (Флоренски 2018: 205).

Шта се крије иза ових смелих идеја? Пођимо од уметничке тј. естетске природе лексема. Она је најуочљивија код тзв. неологизама у песништву где се аутори поигравају како са значењским тако и са гласовним слојем у језику (безьеница, љубавни неодвој код Лазе Костића; лулушка код Душка Радовића, хладновити ветар код Душана Ашића). Ипак, из речи овог мудрог мислиоца може се наслутити да он лингвистичку креативност схвата далеко дубље и шире, а самим тим и модерније. Наиме, сваки творбени механизам (в. Ашић 2014: 49; Ребул 2017: 27; Мешлер 2020: 68) је креативни чин сам по себи, јер се у стварању новог облика речи покреће целокупни мисаоно-језички капацитет човека, а свака реч је најпре била неологизам.

У свом замашном теоријском делу о језику и мисли Флоренски се бави фонетско-фонолошким, али и семантичким аспектом речи. Позивајући се на древну источњачку мисао и истичући тиме важност ослањања на традицију у научном сагледавању и испитивању (в. Мунен 1996), аутор објашњава да „индуска лингвистика, на пример - првенствено ослоњена на само-проматрање са окултно-соматске стране, на искуство сазнајне расподеле пране, постулате послате произвољно у ове или оне органе - успоставља четири концепта или четири слоја у нашој речи". Реч, дакле, постоји у: 1. мозгу примарно, нара, према апсолутном космичком плану или атман; 2. у плућима, посредно, пасианти, према каузалном космичком плану, или карана; 3. у грлу - видљиво, мадиама, према астралном космичком плану, или суксма и најзад у нашој свести (Флоренски 2018: 142).

Иначе, у реч, као такву, уграђена је антиномија унутрашњег (значењског) и спољашњег (материјалног). Удубити се у ту антиномију, по руском филозофу, значи удубити се у првобитну антиномију језика. Овде аутор задире и у постојање и природу основног праисторијског протојезика, који је (в. Ашић 2014: 22; Ребул 2017: 25) имао далеко ближи и природнији однос између означитеља и означеног. Јасно је да се Флоренски у својим разматрањима о језику наставља на учења Абелара, Порт Роајала и Хумболта (Ашић 2014: 149), а бави се и Де Сосировим дихотомијама. 
Реч је за Флоренског централни појам у науци о језику и у теоријском и у металингвистичком смислу. Захваљујући речима, човек је у стању да мисли, јер се помоћу њих обликују концепти и врши категоризација стварности: „Исто тако нема таквог механизма, колико год сложен он био, који не би могао бити описан речима. Нема и не може бити. Дар речи је на све примењиви дар, и област речи није мања од области сазнања, ако чак није и већа. Све што сазнање раствара претвара се у реч" (Флоренски 2018: 145).

Он пореди реч са организмом, те у телу речи разликује скелет, чија је главна функција да држи тело и даје му облик, и остала ткива, која у себи носе сами живот. Прво је фонема, а друго морфема. Морфема представља везивну карику између фонеме и унутрашње форме речи, или семеме. Говорећи о везивној карици Флоренски се, много пре Чомског, позива на његову централну идеју да је језик веза између звука и значења (Чомски 2000). Он исправно запажа да се у морфеми испољава веза између семантике и физичко-физиолошко-неуролошке природе гласа. Не чуди стога што он тврди да у науци о језику морфологија и лексикологија морају бити примарне. Суштина језичке и мисаоне креативности налази се у нашој могућности да стварамо речи и појмове.

Говорећи о изговарању речи аутор (Флоренски 2018: 203) објашњава да успостављајући изотропску комуникацију између тачака, ми директно повезујемо било које две тачке једну са другом. Тако изговарање речи можемо упоредити са таквим додиривањем спознајног субјекта и спознаваног објекта по геометријској изотропи: иако остају просторно раздвојени, они су међусобно повезани. Он закључује да је реч онтолошки изотропа. Као да кроз њега говори сам Де Сосир, аутор нам поручује да су означитељ и означено нераскидиво повезани. Питање које бих поставила је зашто се у западној науци о језику нико не позива на руског филозофа.

На другом месту он објашњава да свакој речи, а подједнако и њиховим склоповима, одговара нека очигледност, и та се очигледност у суштини ни по чему не разликује од сликовитости физичких модела или математичких симбола (Флоренски 2018: 203). Флоренски као да овде заступа формално-теоријски приступ значењу речи (в. Ашић 2014: 93) у којем се оно може представити логиком предиката. Ипак, он такав правац, који ће тек у XX веку наступити у науци, мада се наслућује код Абелара и Граматике Пор Роајала (Ашић 2014: 149), спомиње, додајући да „[а]ко нам навика и површност мишљења при употреби речи не дају да се задржимо на свакој од њих и да се истински науживамо у њиховој уметничкој вредности, у њиховој посебности, онда и навика и површност мишљења, које често иде једним те истим путевима, бришу и пластику самих представа, на пример, механичких модела, подривају њихову јасност, лишавају дражи њихово богатство боја; док представама остаје само њихова службено-помоћна дужност" (Флоренски 2018: 148).

Овде Флоренски заузима јасан филозофски став о естетској функцији језика, коме придодаје и веома оргиналан, когнитивистички став о мишљењу које се такође не може свести на пуко баратање концептима, већ је по својој природи дубоко креативан процес. 
И ми се слажемо са њим и склони смо тврдити да се тајна језика не може у потпуности објаснити минималистичком генеративистичком граматиком Н. Чомског и сви нивои језичке креативности свести на операције мув и мери (в. Ашић 2014: 77).

Чудесност језика и мишљења се једино кроз уметност могу објаснити, јер уметност не разваљује стеге само семантичке, већ и синтаксичке прихватљивости, као што показују следећи стихови ${ }^{4}$ великог песника Момчила Настасијевића, где се уметник поиграва како са значењским тако и са граматичким нивоом у језику:

Врелини овој // бризгај о бризгај, врела // То иза сна, знам,// златан прах остане по њој.

(Сан у подне)

Тамом на зенице // отворим твоју таму // ја, о једини ја. (Јединој)

\section{4. Запажања о синтакси}

Ипак, код овог смелог мислиоца и синтакса у анализама језичке датости има значајно место:

„Ако полазимо од појединих речи, које чине говор, од Worter до mots, онда физику чине представе и симболи, системи представа и симбола, систем система представа и симбола, систем система система итд. итд., тј. на крају крајева речи и склопови речи. Ако, пак, крећемо од повезаности речи, од континуираног говора, који се рашчлањује на речи, тј. ако за основу узмемо Worte, paroles, тада се испоставља да је физика описивање, систем описивања, систем система описивања, систем система система итд. итд.; тада у физици максимално треба видети говор и скуп говора" (Флоренски 2018: 120).

На овом месту аутор повезује основне синтаксичке принципе са физичким законитостима, а реченицу посматра као систем. А то што је физика заправо говор, односно скуп говора, сведочи о његовој посве савременој убеђености да језик подржава мишљење, те да је његова основна функција когнитивна (Мешлер 2020: 63). Овај став се још јасније очитава у наставку овог пасуса који се, међутим, такође бави и везом између лексикологије и синтаксе:

„Оба угла гледања на језик су антиномично повезана: колико год далеко ишла анализа језика, он је увек и реч (дата у реченици) и реченица (састављена од речи). Оно што се уопште говори о језику дословно се и нарочито понавља и о физици. И из једног и из другог угла гледања физика није ништа друго до језик, и то не било који, не измишљени, већ управо онај језик којим сви ми говоримо, с тим што је само ради подесности и добитка времена донекле обрађен" (Флоренски 2018: 120).

\footnotetext{
${ }^{4}$ Доступно на: < http://zephyroswind.blog.rs/blog/zephyroswind/generalna/2011/11/09/momcilonastasijevic-izbor-pesama>, 20.10.2020.
} 
Еквиваленција између структуре науке и структуре језика је сада потпуна. Што се синтаксичке анализе тиче, у језику су, по Флоренском, оба нивоа подједнако важна, јер се он испољава како кроз лексеме, тако и кроз граматичке конструкције.

Ипак, на другом месту аутор указује на непримерност апстрактног уопштавања реченица, тако популрану у савременој чомскијевској лингвистици. Он наводи да саму реченицу одређују речи из којих се она састоји, и изван речи она не постоји (Флоренски 2018: 121). Веома је занимљив његов став да врсте речи зависе од врсте реченица, и обрнуто, врсте реченица зависе од врсте речи. Ово говори о контекстуалној природи лексема о којој ће крајем XX века писати Пустојевски у свом Генеративном лексикону (Пустојевски 1995). Тако његов генеративни механизам коерције своју претечу има у следећем исказу:

„Реч, посматрану уско треба посматрати као реченицу савијену у клупко и чак као цео говор, а реченицу као слободно развијену реч” (Флоренски 2018: 122).

Из овога проистиче да се реч може и мора сматрати нуклеусом реченице. Веома је занимљиво што се у својој књизи Флоренски дотиче чак и прагматике. Примера ради, он показује да се значење тј. семема речи мења у зависности од контекста у којем је реч изговорена, те спомиње нпр. ироничну интерпретацију исказа (Флоренски 2018: 147). Филозоф на врло вешт и јасан начин доказује да значење речи није статичка, већ динамичка категорија, као и да се оно непрекидно прилагођава ситуационим параметрима у којима је изговорена.

\section{5. О симболима}

Тема књиге Павла Флоренског коју анализирамо у овом раду није само језик, односно његова структура, особине и функције, већ и процес мишљења. Управо зато он доста пажње посвећује симболима или представама, које су кључни елементи наше мисаоне делатности. Готово невероватно звучи ово предвиђање модерних когнитивистичких теорија, попут Џекендофове (1993), који у својој књизи уводи тзв. граматику конщепата. У њој се објашњава начин настанка појмова и манипулисања њима. С друге стране, руски филозоф, не позивајући се на Курс опште лингвистике Фердинанда де Сосира (1971), говори о вези имеђу симбола и оног што овај означава:

„Стварност описујемо симболима или представама. Али симбол би престао да буде симбол и постао би у нашој свести обична и самостална реалност, потпуно неповезана са оним што симболише, када би предмет описивања стварности био једино сама та стварност: описивање, уједно с тим, мора да има у виду и симболички карактер самих симбола, тј. да се посебно напреже како би се стално држало у исти мах и симбола и онога што он симболише" (Флоренски 2018: 198). 
Јасно је да Флоренски овде говори о томе да речи не означавају предмете као делове стварности, већ појмове о њима које је створио наш ум. Он потом поручује: „Описивање мора бити двоструко. То се постиже критиком симбола" (Флоренски 2018: 198).

Стварност се, дакле, у нашем језику приказује онаквом какву ју је претходно створио наш ум, а језик, по Флоренском, као и по Де Сосиру, није номенклатура већ апаратура за представљање реалности. Што се самих концепата тиче, они морају бити сврсисходни, правилни и прихватљиви (Флоренски 2018: 17).

„Да би представе биле сврсисходне, њима приписујемо ознаке, одређења, скраћења, једном речју све што је по својој вољи слободно можемо да додајемо и одбацујемо.”

Ово значи да људски ум слободно барата концептима, непрекидно их филтрира и обогаћује.

„Да би представе биле правилне, приписујемо им оне искуствене податке који су послужили при стварању представе."

Овде Флоренски улази у саму срж стварања концепата, које се заснива на нашем искуству и категоризацији објективне стварности.

„Да би представе биле прихватљиве, приписујемо им оно што је дато у својствима нашег духа".

Сама структура и природа концепата одговара структури и природи нашег духа, тј. сагласна је са процесом мишљења и поимања. А да се концепти временом развијају, тј. да нису статична већ динамичка категорија, речено је у следећем пасусу:

„Да ли је представа правилна или није, то можемо једнозначно одлучити у потврдном или одричном смислу, али једино ће та одлука одговарати савременом (додајмо: и индивидуалном у датом моменту) стању нашег искуства и можда у будућности бити измењена скупљањем зрелијег искуства."

Флоренски наставља да тумачи природу симбола и његове везе речима:

„Шта, ипак, значи обузданост представе, било у науци, било у уметности? Како може представа да се не претвара у предмет трансцендентан опису, већ да буде његово оруђе, иманентно знању. О чему сведочи та нераскидива веза представе и описа? О чему другом, ако не о једнородности описа и представа? Другим речима: сам опис је представа или систем представа, али узети критички, тј. управо као представе; и, обрнуто, представе, садржане у опису, нису ништа друго до угрушци, згуснути концентрати и кристали истог тог описа, тј. сам опис, и то онај који крајње живо и већ сад - сада одмах - стреми ка самосталности" (Флоренски 2018: 18).

Захваљујући речима ми господаримо нашим искуством и нашом представом о свету. А будући да међу њима постоји нераскидива веза, ми смо у стању спознати суштину сваког концепта. Али у процесу генезе језика речи се осамостаљују и постају више од етикета за концепте; наиме оне имају своју посебну филозофску и естетичку вредност, па чак могу повратно утицати и на природу самих појмова. 
Приступ језику Павла Флоренског није импресионистички већ истински научан. Он у својој књизи дефинише научно описивање за које алегоријски каже да је „слично високом морском таласу: по њему беже таласи изазвани пролажењем брода; њихова површина је избраздана њихањем које стварају пераја великих риба, а тамо - све мање и мање мрешкање, укључујући и најмање, можда, микроскопско мрешкање" (Флоренски 2018: 19).

У њему се дакле иде од општег ка посебном. У наставку аутор наводи да је и само описивање стварности језиком по својој природи истоветно научном, те да се наше представе тј. концепти састоје од све ситнијих и ситнијих атома-концепата. Тиме он век и по пре актуелних когнитивних истраживања осликава архитектуру људског ума, која је попут „шареног тепиха испреплетаних представа”. Ово је у тесној вези са оним што о свету каже астрофизичар Карло Ровели (2017: 122-123):

„Када размишљамо о свету, организујемо га у целине: групишемо или поприлично рашчлањујемо континуитет мање-више једноличних и стабилних процеса како бисмо боље комуницирали са њима. Групишемо стене у скупину коју називамо Мон Блан и замишљамо их као једну целину. Бележимо линије по свету које га рашчлањују на делове: успостављамо границе, присвајамо свет сводећи га на комаде. На тај начин функционише и структура нашег нервног система [...] Ствари, као конщепти, су фиксне тачке у неуронској динамици које су резултат повратних структура у чулним осећајима и процесима узастопних обрада."

И један и други научник крећу од физике да би уз помоћ њених принципа објаснили структуру људског ума. Павле Флоренски, много пре но што ће они настати, мири класичан и формалан (монтегјуовски) приступ семантици:

„Свакој представи и сваком симболу, колико год они били сложени и тешки, ми дајемо име, а то значи да они већ самим тим јесу реч, да улазе у описивање као реч, а друкчије и не би могли да уђу. Свака од тих речи може да буде откривена: представу описујемо, математички симбол објашњавамо и одређујемо” (Флоренски 2018: 20).

Он, у извесној мери, изједначава концепт и симбол. Јер, да би се спознали и једни и други, потребан је језик.

„Значи, уместо представа и симбола можемо подметнути њихове описе, који носе у себи представе и симболе, а њих изнова можемо открити тако што ћемо уместо њих поставити њима одговарајуће описе. И тако даље. Сваки симбол и сваку представу вишег реда можемо заменити тако што ћемо их описати користећи представе и симболе нижег реда, све до реченица као примарних описа" (Флоренски 2018: 20).

Речи, као што смо већ рекли, нису пуки означитељи концепата; захваљујући њима сложена стварност се може дубље и боље спознати, и то тако што се сами појмови могу поједноставити. Сходно томе, Флоренски истиче да у „целокупној науци нема баш ничег, колико год оно изгледало сложено и тајанствено, што се усменим говором не би могло рећи, подједнако тачно, мада не и подједнако комфорно и кратко” (Флоренски 2018: 15). Дакле, и најкомпликованији математички и физички модели могу се лингвистичким путем објаснити: 
„Физика описује стварност диференцијалним једначинама и другим, томе сличним формулама. Али нема такве диференцијалне једначине, а ни било које друге такве математичке формуле која не би могла бити испричана. Нема и не може бити" (Флоренски 2018: 19).

Последњи цитат у овом раду сведочи о томе колика је за Павла Флоренског моћ људског (природног) језика и колико је он, на неки начин, моћнији од сваког вештачког, формалног језика.

\section{6. Закључак}

За оригинална научна решења потребни су огромно искуство и образовање, логичка доследност, али и интуиција. Флоренски у својој књизи, написаној много пре генеративистичке и когнитивистичке револуције у лингвистици и когнитивним наукама, открива тајне језика и мишљења. Он показује, много пре чувене дебате Пијаже-Чомски, да мишљење претходи језику, али да га истовремено језик обогаћује и продубљује. Реч је централна категорија у језику, која се, с једне стране ослања на појам, а с друге га стране, трансцендентално превазилази тако да све што је њему својствено остаје достпуно нашем уму. Усудили бисмо се, на крају рада, да кажемо да овај даровити филозоф и надахнути теолог, на овај индиректан начин, показује да је језик човеку дар од Бога. Јер, као што је показао на три стотине страница свог дела, језик нам омогућује да спознамо оба лица света и свемира, овострано и онострано.

\section{ЛИТЕРАТУРА}

Ашић 2014: Т. Ашић, Наука о језику, Београд: Завод за уџбенике.

Де Сосир 1971: F. de Saussure, Cours de linguistique générale, Paris: Payot.

Мешлер 2020: J. Moeschler, Pourquoi le langage?, Paris: Armand Colin.

Мунен 1996: Ž. Munen, Istorija lingvistike, Beograd: Biblioteka XX vek.

Пустејовски 1995: J. Pustejovsky, The generative lexicon, Cambridge, MA: Bradford Books/MIT Press.

Ребул 2017: A. Reboul, Cognition and communication in the evolution of language, Oxford: Oxford University Press.

Ровели 2018: C. Rovelli, L'ordre du temps, Paris: Flammarion.

Флоренски 2018: П. Флоренски, Мисао и језик, Београд: Логос.

Чомски 2002: N. Chomsky, Language and Mind, Cambridge: Cambridge University Press.

Џекендоф 1983: R. Jackendoff, Semantics and cognition, Cambridge, MA: MIT Press. 
Tijana Ašić

\section{THE WORK OF PAVEL FLORENSKY "THE THOUGHT AND THE LANGUAGE" IN THE LIGHT OF THE CONTEMPORARY ANALYSIS OF LANGUAGE AND COGNITION}

\section{Summary}

In this paper we introduce, analyze and comment the fundamental ideas of the Russian philosopher Pavel Florensky concerning the phenomena of Language and Cognition. As the most important, we consider his conclusions and findings regarding the nature of the words, as the basic elements of the Language and the concepts as the nuclei of cognition. Although Florensky states that the word is the most important element of Speech, in his seminal book "Thought and Language" he also deals with syntax and even pragmatics. Our aim is to show the relation between his hypothesis and the modern trends in linguistics and cognition.

Key words: Pavel Florensky, language, cognition, word, semantics, syntax, pragmatics. 